\title{
La disciplina urbanística
}

\author{
Ricardo García Macho ${ }^{1}$ y José Luis Blasco Díaz
}

Sumario: I. ADMINISTRACIÓN Y COACCIÓN. II. LOS FINES DE LAS SANCIONES URBANÍSTICAS. 1. Consideraciones previas. 2. La necesidad de efectividad de las sanciones urbanísticas. III. DISTRIBUCIÓN DE COMPETENCIAS SOBRE DISCIPLINA URBANÍSTICA ENTRE EL ESTADO, COMUNIDADES AUTÓNOMAS Y ENTES LOCALES. 1. Breve referencia al estado de la cuestión. 2. Las competencias de los Entes locales sobre disciplina urbanística. IV. LA PROTECCIÓN DE LA LEGALIDAD URBANÍSTICA. 1. Contenido y obligatoriedad. 2. Supuestos de actuaciones sin licencia ni orden de ejecución o en contra de sus determinaciones. A) Actuaciones en curso de ejecución. a) Inicio del expediente y adopción de medidas preventivas: requerimiento de suspensión y de legalización. b) Legalización de actuaciones y medidas de restitución. B) Actuaciones totalmente terminadas y plazo de reacción. 3. Supuesto de actuaciones ilegales amparadas en una licencia u orden de ejecución. V. EL RÉGIMEN SANCIONADOR URBANÍSTICO. 1. La competencia sancionadora. 2. Las infracciones urbanísticas y sus responsables. 3. Las sanciones urbanísticas. Tipología y extensión.

\section{ADMINISTRACIÓN Y COACCIÓN}

La actuación de la Administración se lleva a cabo dentro de unos parámetros o principios, los cuales le proporcionan unas líneas de orientación permanente, que la van a ayudar en su proceder más allá de las situaciones concretas que hay que resolver en la aplicación de cada norma . Estos parámetros o principios (proporcionalidad, economía, eficiencia, transparencia, etc.) hacen efectiva la racionalidad de la acción administrativa y proporcionan líneas de orientación permanente, y así lo entiende el legislador que elaboró la Ley 30/1992, de 26 de noviembre (LRJ-PAC) en su artículo 3, que se refiere a los principios generales que orientan y determinan la acción administrativa. Es cierto también que en bastantes casos estos parámetros o principios se

1 Catedrático de Derecho Administrativo. Universidad Jaume I.

2 Profesor Titular de Derecho Administrativo. Universidad Jaume I.

3 Véase en este sentido A. Nieto, Derecho Administrativo Sancionador, Madrid, 2000, p. 41 y ss. y E. Schmidt-Assmann, La teoría general del Derecho Administrativo como sistema, Madrid, 2003, p. 347 y ss. 
han convertido en principios generales del derecho (proporcionalidad, seguridad jurídica, buena fe, protección de la confianza legítima, etc.), que ayudan en la aplicación de la norma e incluso en el desarrollo de la actuación de la Administración, como han destacado E. García de Enterría-T.R. Fernández ${ }^{4}$, pero que también plantean algunos peligros e incluso abusos en su utilización, no sólo de los principios generales, sino de los principios en general, como ha puesto de manifiesto A. Nieto 5 .

La efectividad de estos principios y de la propia norma depende de su cumplimiento, lo cual depende también, y juega un papel importante, del grado de relevancia social y aceptación que tengan ambos. La realización y efectividad del derecho incluye la ejecución forzosa ${ }^{6}$ y la potestad sancionadora, teniendo en cuenta que estas dos últimas fases se incardinan en un proceso que comienza con la legislación, sigue con la aplicación concreta de esa normativa abstracta, y termina, si se hace necesario, con la coacción, lo cual incluye la ejecución forzosa y la potestad sancionadora?.

La efectividad del ordenamiento jurídico depende no sólo de su capacidad de coacción, sino en una gran medida de la aceptación que obtenga entre los ciudadanos, de tal manera que la obtención de la aceptación de la acción administrativa no se agota en el reconocimiento democrático y de legitimación, sí bien estos dos principios son esenciales para una efectiva puesta en práctica del ordenamiento jurídico ${ }^{8}$. Sin embargo, debe ponerse de relieve que en una sociedad compleja cada día es más complicado para el legislador y la Administración, debido a la necesidad que tienen de cooperación con los ciudadanos, alcanzar sus objetivos en contra de la voluntad de los individuos a los que se dirige la norma. Este planteamiento se manifiesta de forma nítida en la praxis del ordenamiento urbanístico, que necesita reflexión y una reordenación en profundidad a la luz del servicio a los intereses generales y los demás preceptos constitucionales que se ocupan de la materia, en la dirección iniciada por el Texto Refundido de la Ley de Suelo, aprobado por el Real Decreto Legislativo 2/2008, de 20 de junio.

Los principios que informan las normas y la aplicación de la propia norma deben estar sometidos a control, y en este sentido la sanción juega un papel instrumental,

4 Una síntesis de las ideas desarrolladas especialmente por E. García de Enterría se encuentran en Curso de Derecho Administrativo I, decimocuarta edición, Cizur Menor, 2008, pp. 85 y ss.

5 Como destaca este autor, la utilización de los principios de manera prolífica conduce a una inflación de principios que crean un sistema jurídico artificial, e incluso otorgan mayor poder a los jueces, que son quienes los aplican; en Derecho Administrativo Sancionador, op.cit. (cita 1), pp. 39 y ss.

6 La ejecución forzosa está vinculada a la autotutela administrativa en el Derecho español (art. 95 LRJ-PAC), pero no ocurre lo mismo en otros Derechos como el francés, tal como destacan E. García de Enterría-T.R. Fernández, Curso de Derecho Administrativo l, op.cit. (cita 2), pp. 785 y ss., o bien en el alemán en el que ejecución forzosa y sanciones administrativas tienen una estrecha relación, pues se considera que ambos conceptos forman parte de la coacción, que es un instrumento de control de la acción administrativa.

7 Vid. sobre la cuestión Ch. Waldhoff, "Vollstreckung und Sanktionen”, en Grundlagen des Verwaltungsrechts, tomo III, ed. de W. Hoffman-Riem/ E. Schmidt-Assmann/ A. Vosskuhle, München, 2009, pp. 270 y 271.

8 En profundidad sobre un tema esencial para que el ordenamiento jurídico alcance los objetivos que se propone, vid. A. Vosskuhle, Das Kompensationsprinzip, Tübingen, 1999, pp. 93 y ss. 
de control administrativo. Debe tenerse en cuenta que la capacidad de dirigir o pilotar la acción administrativa depende de su control por la propia Administración, y un instrumento para ello lo constituye la sanción administrativa. Esta es una acción de gravamen de la Administración contra aquellos individuos que infringen la norma jurídica9, por lo que existe una vinculación entre la norma y la sanción, de tal forma que se muestran ambas como las dos caras de una misma moneda.

\section{LOS FINES DE LAS SANCIONES URBANÍSTICAS}

\section{Consideraciones previas}

La potestad sancionadora en general tiene una finalidad de restitución de la legalidad infringida, por lo que existe un carácter de intencionalidad entre la sanción y la norma. En este sentido, las sanciones pueden ser de tipo represivo, restitutivo o bien preventivo, y se instruyen frente a una norma que impone una conducta de ordenar algo o bien prohibirlo.

En la esfera del Derecho Urbanístico de manera muy especial la potestad sancionadora debe tener una estrecha vinculación con la aceptación de ese ordenamiento por la ciudadanía, al menos esa es la conclusión, en nuestra opinión, que el legislador y en general los poderes públicos deberían extraer de la falta de eficacia de las sanciones urbanísticas hasta este momento en nuestro país, lo cual es fácilmente perceptible en los ensanches de nuestras ciudades, en las costas, e incluso en las zonas ya consolidadas del centro de nuestras ciudades. En definitiva, a lo largo y ancho de la geografía española se puede percibir las frecuentes infracciones urbanísticas cometidas en la gestión de la ordenación urbanística, y la consiguiente falta de sanción.

En materia de urbanismo la participación de los ciudadanos en el procedimiento de toma de decisiones es esencial, dado que los intereses económicos en juego son de gran envergadura y afectan de manera decisiva a la calidad de vida del ciudadano, por lo que el servicio a los intereses generales se hace perentorio ${ }^{10}$. El Texto Refundido de la Ley de Suelo de 2008 ha partido de una adaptación en profundidad de la materia a la Constitución, especialmente a sus artículos 45 y $47^{11}$, lo cual destaca la Exposición de motivos de la norma (punto II), y también en su articulado con especial hincapié en los artículos 2 y 4 . En ese artículo 2 se establece una fuerte conexión

9 Se trata de una definición convencional de sanción administrativa; ampliamente sobre el tema vid., por todos, E. García de Enterría-T.-R. Fernández, Curso de Derecho Administrativo II, undécima edición, Cizur Menor, 2008, p. 163 y ss. y L. Parejo Alfonso, Derecho Administrativo, Barcelona, 2003, p. 775

10 Vid. sobre el tema R. García Macho, "Ordenación del territorio y urbanismo en el Estatuto de Autonomía Valenciano”, en Comentario al Estatuto de Autonomía de la Comunidad Valenciana, dir. J. M. Baño León, Cizur Menor, 2007, pp. 673 y ss.

11 En profundidad sobre la materia vid. M. Vaquer Caballería, “Estudio preliminar (Constitución, ley de suelo y ordenamiento territorial y urbanístico", en Comentarios al Texto Refundido de la ley de suelo, L. Parejo Alfonso/ G. Roger Fernández, Madrid, 2009, pp. 27 y ss. 
entre el interés general que el constituyente instauró en el artículo 47 de la Constitución en la regulación del suelo y la acción urbanística, con la utilización racional de los recurso naturales, a lo que se refiere el artículo $45.2 \mathrm{CE}$, y en el artículo 4 a partir del apartado c) y siguientes se refuerza la información y participación ciudadana en relación con el suelo y urbanismo ${ }^{12}$, con una conexión necesaria entre ambos derechos, pues no es posible una adecuada participación del ciudadano en las cuestiones que le conciernen sin poder acceder a la información que detenta la Administración, e incluso que la propia Administración suministre información sin necesidad de solicitud, teniendo en cuenta la perspectiva de un procedimiento administrativo multifunción ${ }^{13}$.

Las sanciones en materia de disciplina urbanística deben ser enfocadas en el futuro, si se pretende que esas sanciones tengan eficacia, y realmente puedan ser un instrumento de control del urbanismo en la acción de la Administración, desde la perspectiva de una amplia participación del ciudadano en la Ordenación del territorio y urbanística. Solamente desde esa perspectiva la coacción administrativa en el urbanismo tendrá un aceptación entre la ciudadanía. En efecto, hoy en día la Administración en determinados ámbitos de referencia, entre los cuales se encuentra el Derecho Urbanístico, necesita en su actuación las técnicas de la cooperación, además de la coacción, para poder dirigir con eficacia esa acción administrativa.

\section{La necesidad de efectividad de las sanciones urbanísticas}

Si se pretende que en el futuro no siga siendo necesario decir que la indisciplina es una lacra de nuestro urbanismo, tal como pone de manifiesto T.-R. Fernández ${ }^{14}, y$ que, por tanto, las sanciones urbanísticas tienen poca eficacia o ninguna, se hace imprescindible un replanteamiento de todo el Derecho Urbanístico a la luz de la Constitución. En primer lugar del artículo 25.1 que se incumple con excesiva frecuencia, pues bastantes de la infracciones administrativas en la materia no son sancionadas, e incluso del artículo 45.3, el cual establece que la infracción de las normas medio ambientales llevará aparejado sanciones penales ${ }^{15}$, y en su caso administrativas. Estos preceptos constitucionales deben ponerse en relación con el artículo 47 de la Constitución, dado que la norma y su sanción, como se ha dicho más arriba, son las dos caras de una misma moneda, y si la utilización del suelo debe hacerse según el interés general y evitar la especulación, el incumplimiento de estos principios acogidos ya en el Texto

12 De estas cuestiones se han ocupado ampliamente L. Parejo Alfonso/ G. Roger Fernández, Comentarios al Texto Refundido de la ley de suelo, op.cit. (cita 9), pp. 120 y ss. y 144 y 145

13 Sobre el tema, y desde la perspectiva de cómo debe entenderse, en nuestra opinión, el procedimiento administrativo multifunción, lo que es aplicable de manera especial a la ordenación urbanística, vid. R. García Macho, "Procedimiento administrativo y sociedad de la información y del conocimiento", en La transformación del procedimiento administrativo, editor J. Barnés, Sevilla, 2008, pp. 207 y ss.

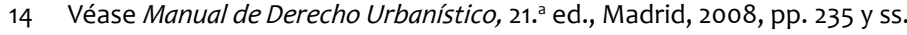

15 En profundidad desde la perspectiva del ordenamiento penal vid. E. Górriz Royo, Protección

294 penal de la ordenación del territorio, Valencia, 2003, pp. 480 y ss. 
Refundido de la Ley de Suelo en su artículo 3.1 y en otros ${ }^{16}$, debe llevar como consecuencia la imposición de sanciones administrativas.

La protección efectiva de la legalidad urbanística necesitaría, por una parte, una participación lo más amplia posible de los ciudadanos en la ordenación del territorio y urbanismo, y por otra, que el principio de legalidad urbanística se cumpla de manera estricta en la práctica ordinaria. Para que esto último sea así debe replantearse en profundidad toda la materia de legalización de actuaciones urbanísticas contrarias a derecho, práctica común en el Derecho español, tal como ha puesto de manifiesto E. Desdentado Daroca ${ }^{17}$, como así mismo la utilización de la institución de la demolición cuando así esté previsto en la ley, lo cual no parece que sea así, puesto que la jurisprudencia parte de la excepcionalidad de la demolición, y una tendencia en las revisiones de los planes de urbanismo a la legalización de las ilegalidades ${ }^{18}$. Por otra parte, en la consecución de la eficacia de la institución de la demolición debe incluirse la ejecución de las sentencias que ordenan la demolición, lo cual con frecuencia no se produce con efectos demoledores para el Estado de Derecho ${ }^{19}$.

Frente a esta descripción del panorama urbanístico español hay una sentencia significativa del Tribunal Europeo de Derechos Humanos (Saliba c. Malta), de 8 de noviembre de 2005, en la que se plantea si la demolición de un almacén construido sin licencia urbanística se ajusta a derecho o no. La cuestión es si el uso de los bienes, en este caso el derecho de propiedad se ajusta al interés general, y si en la intervención en la propiedad se ha respetado el principio de proporcionalidad, pues "se debe mantener un equilibrio justo entre las exigencias del interés general de la comunidad y los requisitos de protección de los derechos fundamentales de la persona" (apartado 36). El TEDH constata que la orden de demolición tuvo como finalidad, tal como dicen los tribunales internos, el restablecimiento de la norma de derecho frente a una construcción abusiva e ilegal, por lo que se hace prevalecer la conservación del medio ambiente y el cumplimiento de las normas de urbanismo (apar. 44). El TEDH vincula medio ambiente y cumplimiento de las normas de urbanismo, poniendo de manifiesto, tal como establece L. Martín-Retortillo ${ }^{20}$, que el medio ambiente depende en gran

16 Así, por ejemplo, en el artículo 7 que pretende erradicar o al menos situar las plusvalias en unos términos no especulativos, las “expectativas urbanísticas”, y en todo el Título III (art. 21 y ss.), que se ocupa de las valoraciones del suelo.

17 En este sentido se manifiesta la autora de manera nítida, poniendo de manifiesto como el Derecho Urbanístico formalmente goza de unos sistemas de control realmente sofisticados, pero en la práctica su eficacia es mínima, fomentando de manera indirecta como consecuencia de esta circuntancia la corrupción; “El control de la legalidad urbanística ¿qué legalidad?”, y la bibliografía allí citada, en III Congreso de la Asociación Española de Profesores de Derecho Administrativo, Sevilla, 2009, pp. 108 y ss.

18 Sobre la cuestion vid. S. González-Varas Ibáñez, Urbanismo y Ordenación del territorio, 5. ${ }^{\text {e ed., }}$ Cizur Menor, 2009, pp. 895 y ss.

19 En profundidad sobre el tema, partiendo del hecho cierto de la frecuente inejecución de las sentencias de los tribunales en general y en particular en materia de urbanismo, y las vías par conseguir cambiar esta realidad tan perversa, vid. G. Geis i Carreras, La ejecución de las sentencias urbanísticas, Barcelona, 2009, especialmente pp. 285 y ss.

20 Vid su sugerente comentario a esta sentencia en "Orden de derribo de lo edificado sin licencia y protección del medio ambiente”, en Revista Española de Derecho Administrativo, n. ${ }^{\circ}$ 130, 2006, pp. 356y ss. 
medida de la política urbanística y de ordenación del territorio. Parece evidente que en materia de ordenación del urbanismo la disciplina urbanística es esencial, y tal y como dice el TEDH su salvaguardia "va a disuadir a otros infractores potenciales" (apar. 46).

Debe también ponerse de relieve que la perdida de efectividad de la disciplina urbanística implica la perdida de legitimidad del sistema, tal como ha destacado L. Parejo Alfonso ${ }^{21}$, dado que los bienes jurídicos vulnerados se refieren a un medio ambiente adecuado, que incluye un uso racional de la naturaleza en general y del suelo en particular, además de que la indisciplina urbanística genera el desarrollo de una ciudad irracionalmente concebida e insolidaria, todo lo cual afecta directamente a la calidad de vida del ciudadano.

\section{DISTRIBUCIÓN DE COMPETENCIAS SOBRE DISCIPLINA URBANÍSTICA ENTRE EL ESTADO, COMUNIDADES AUTÓNOMAS Y ENTES LOCALES}

\section{Breve referencia al estado de la cuestión}

La materia urbanismo es asumida como competencia plena por las Comunidades

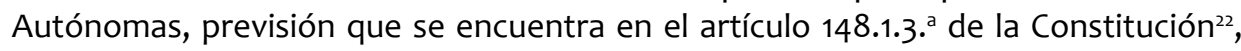
pero que no había sido desarrollada con plenitud hasta que se dictó la sentencia 61/1997 del Tribunal Constitucional, hasta tal punto que una gran parte de las Comunidades Autónomas han promulgado leyes sobre la materia a partir de esta sentencia. Por otra parte, el Estado dispone de una serie de competencias en el artículo $149.1,1 .^{a}, 8 .^{a}, 13 .^{a}, 18 .^{a}$ y $23 .^{a}$, que le permiten una intervención en la materia urbanismo, aunque no sea de forma directa, lo que plantea una integración de estas competencias con la de urbanismo de las Comunidades Autónomas, como ha puesto de manifiesto el Tribunal Constitucional, de manera muy especial, en las sentencias $61 / 1997$ y $164 / 2001^{23}$.

Debe también destacarse que sobre urbanismo los Entes locales disponen de competencias que comparten con las Comunidades Autónomas, como ya incluso antes de la sentencia 61/97 había determinado la legislación autonómica sobre urbanismo. Las competencias de los Entes locales proceden de la Ley 7/1985, de 2 de abril, reguladora de las Bases de Régimen Local (LRBRL), que en su artículo 2.1 establece que las leyes del Estado y Comunidades Autónomas deben asegurar a los Entes loca-

21 En La disciplina urbanística, Madrid, 2006, pp. 13 y ss.

22 Vid. S. Muñoz Machado, Derecho Público de las Comunidades Autónomas l, 2. ed., Madrid, 2007, p. 720 y ss. y R. García Macho, “Ordenación del territorio y urbanismo en el Estatuto de Autonomía Valenciano”, op. cit. (cita 8), pp. 691 y ss.

23 Dice el Tribunal Constitucional, en efecto, en la sentencia 61/97 que "la competencia autonómica exclusva sobre urbanismo ha de integrarse sustemáticamente con aquellas otras estatales que, si bien

296 propiciar, sin embargo, que se afecte puntualmente a la materia urbanística" (f.j. 6-b). 
les, en el ejercicio de su autonomía, constitucionalmente reconocida (arts. 137 y 140 CE) el derecho a intervenir en los asuntos que afecten directamente a sus intereses. Son, por tanto, las leyes del Estado y las Comunidades Autónomas las que determinaran la competencia de los Entes locales, garantizándoles una participación activa en sus asuntos ${ }^{24}$. Desde esta perspectiva el artículo 25.2-d) LRBRL atribuye a los municipios la competencia sobre ordenación, gestión, ejecución y disciplina urbanística.

Desde el punto de vista del Derecho Urbanístico hay una sentencia del Tribunal Constitucional (240/2006, de 20 de julio) que restringe de manera notable el contenido de la autonomía municipal frente a otras de signo contrario que la amplían ${ }^{25}$. Esta sentencia 240/2006 que se ocupa del planeamiento urbanístico de la ciudad de Ceuta, si bien mantiene que esa es tarea esencialmente del municipio (f.j. 13), sin embargo desde un punto de vista de su contenido restringe su autonomía. En efecto, la ciudad de Ceuta goza de autonomía, pero no puede ser considerada igual que la de cualquier otro municipio de la geografía española, pues dispone de un estatuto especial, al que hace referencia la Disposición transitoria quinta de la Constitución de 1978, y a lo que también hace mención el voto particular a esta sentencia ${ }^{26}$. La argumentación del alto Tribunal tiende a diluir el contenido de la autonomía municipal de Ceuta, de tal manera que sufre una restricción cuando aquél dice que "el legislador estatal goza de libertad a la hora de determinar la participación de los entes locales en la actividad urbanística siempre que se respete un núcleo mínimo identificable de competencias que haga reconocibles aquellos entes como una instancia decisoria autónoma" (f.j. 12). Con estos argumentos el Tribunal Constitucional deja abierta la posibilidad de cualquier restricción del contenido material de la autonomía de Ceuta, que es lo que Ileva a cabo en la situación concreta, cuando declara que esa ciudad autónoma sólo tiene competencias en las fases de aprobación inicial y provisional del planeamiento urbanístico.

\section{Las competencias de los Entes locales sobre disciplina urbanística}

El respeto de la legalidad urbanística ha tenido carencias importantes ya desde la época anterior a la Constitución. El Texto Refundido de 1976 en los artículos 225 y

24 No es posible en este contexto entrar en profundidad en un tema tan complejo y sobre el que se la doctrina ha escrito con aportaciones de gran interés científico. Por ello, solamente puede hacerse referencia a una muy breve bibliografía; vid. L. Parejo Alfonso, Derecho Administrativo, 2003, Barcelona, p. 562 y ss.; S. Muñoz Machado, Tratado de Derecho Administrativo y Derecho Público general III, Madrid, 2009, p.997 y ss.; F. Sosa Wagner, “La autonomía local”, en Estudios sobre la Constitución española. Homenaje al Prof. E. García de Enterría, tomo IV, Madrid, 1991, p. 3207 y ss.; J.L. Carro Fernández-Valmayor, "El debate sobre la autonomía municipal”, en Revista de Administración Pública, n. 147,1998, pp. 90 y ss. y J. Esteve Pardo, "Garantía institucional y la función constitcucional en las bases del régimen local", en Revista Espa-

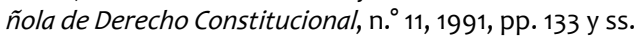

25 Se está aludiendo a las sentencias del Tribunal Constitucional 11/1999, de 11 de julio, a la que más abajo se hará referencia, y la 51/2004, de 13 de abril.

26 El voto particualr del Magistrado J. Rodríquez-Zapata considera que desde esos presupuestos la ciudad de Ceuta debería detentar un mayor papel en la aprobación definitiva de su PGOU, por lo que existe vulneración de su autonomía en la gestión de sus intereses. 
ss. hacía una remisión al reglamento para que regulase el régimen sancionador, y es el Reglamento de disciplina urbanística de 1978 (RDU) el que se ocupa de tal regulación y tipificación. Sin embargo, a partir de la promulgación de la Constitución de 1978, que establece una reserva de ley en materia sancionadora en el artículo 25.1, debería haberse modificado la normativa. Sin embargo, el RDU permaneció vigente, aunque hoy en día sólo se aplica a las ciudades autónomas de Ceuta y Melilla. La causa de tal situación es que la disciplina urbanística debe ser regulada por las Comunidades Autónomas, pues es una materia de ordenación del urbanismo, por lo que a raíz de la sentencia del Tribunal Constitucional 61/97, corresponde a aquéllas su desarrollo.

Desde estos presupuestos una gran parte de las Comunidades Autónomas se han ocupado del la disciplina urbanística en su leyes sobre urbanismo ${ }^{27}$. Sin embargo, alguna Comunidad ha ido más allá, como las Islas Baleares, y ha promulgado una ley que se ocupa exclusivamente de la disciplina urbanística ${ }^{28}$.

Debe destacarse que en la ejecución del urbanismo las competencias corresponden esencialmente a los Entes locales, y en este sentido el artículo 25.2-d) de la LRBRL considera que al municipio le corresponde la competencia para la gestión de sus intereses sobre disciplina urbanística. Ya el Texto Refundido de 1976, que es preconstitucional, en su artículo 184.1 atribuía al Alcalde la suspensión inmediata de los actos de edificación o uso del suelo que se efectuasen sin licencia ${ }^{29}$. A partir de la sentencia del Tribunal Constitucional 61/97 la disciplina urbanística es una competencia que corresponde ejercer esencialmente a los Entes locales, sin perjuicio de que si éstos no la ejercen, en ese caso las Comunidades Autónomas se subrogarían en el ejercicio de tal competencia.

Que la disciplina urbanística es una competencia de los Entes locales se pone de manifiesto en la sentencia del Tribunal Constitucional de11/1999, de 11 de febrero, la

27 Se trata esencialmente de las siguientes normas, con sus eventuales modificaciones y desarroIlos: Ley 7/2002, de 17 de diciembre, Ordenación Urbanística de Andalucía; Ley 3/2009, de 17 de junio, de Urbanismo de Aragón; Decreto Legislativo 1/2004, de 22 de abril, por el que se aprueba el texto refundido de las disposiciones legales vigentes en materia de ordenación del territorio y urbanismo de Asturias; Decreto Legislativo 1/2000, de 8 de mayo, por el que se aprueba el Texto Refundido de las Leyes de Ordenación del Territorio de Canarias y de Espacios Naturales de Canarias; Ley 2/2001, de 25 de junio, de Ordenación Territorial y Régimen Urbanístico del Suelo de Cantabria; Decreto Legislativo 1/2004, de 28 de diciembre de 2004, por el que se aprueba el Texto Refundido de la Ley de Ordenación del Territorio y de la Actividad Urbanística de Castilla-La Mancha; Ley 5/1999, de 8 de abril, de Urbanismo de Castilla y León; Decreto Legislativo 1/2005, de 26 de julio, por el que se aprueba el Texto refundido de la Ley de Urbanismo de Cataluña; Ley 15/2001, de 14 de diciembre, del Suelo y Ordenación Territorial de Extremadura; Ley 9/2002, de 30 de diciembre, de Ordenación Urbanística y Protección del Medio Rural de Galicia; Ley 9/2001, de 17 de julio, del Suelo, de la Comunidad de Madrid; Decreto Legislativo 1/2005, de 10 de junio, por el que se aprueba el texto refundido de la Ley del Suelo de la Región de Murcia; Ley Foral 35/2002, de 20 de diciembre, de Ordenación del Territorio y Urbanismo de Navarra; Ley 2/2006, de 30 de junio, de Suelo y Urbanismo del País Vasco; Ley 5/2006, de 2 de mayo, de Ordenación del Territorio y Urbanismo de La Rioja; Ley 16/2005, de 30 de diciembre, Urbanística Valenciana.

28 Se trata de la Ley 10/1990, de 23 de octubre, de Disciplina Urbanística, modificada por la ley $6 / 1999$, de 3 de abril.

29 Sobre la cuestión véase L. Parejo Alfonso, La disciplina urbanística, op. cit. (cita 19), pp. 52 y 53. 
cual declara que el artículo 6 de la ley del Principado de Asturias 3/87, de 8 de abril, sobre Disciplina Urbanística, es inconstitucional porque permite que la Administración autonómica entre a determinar, suplantando a la Administración local en un juicio de legalidad, si una licencia para construir y sobre usos del suelo es nula o no de pleno derecho, pues ello dice el alto Tribunal "hace jugar la asunción de competencias municipales por la Administración autonómica cuando la Corporación local no suspenda los actos de edificación y uso del suelo realizados al amparo de una sedicente licencia nula de pleno derecho, pues esa apreciación y, en su caso, declaración de nulidad -presupuesto habilitante- se configura como un control de legalidad ejercido por una Administración ajena con el consiguiente debilitamiento de la autonomía municipal" (f.j. 4).

\section{LA PROTECCIÓN DE LA LEGALIDAD URBANÍSTICA}

\section{Contenido y obligatoriedad}

Como venimos sosteniendo, cualquier tipo de actuación contraria al ordenamiento urbanístico debe dar lugar a una reacción de la Administración competente. Ese régimen de intervención se han recogido en la legislación estatal desde la Ley del Suelo de 1975, donde se establecía un sistema que, con pocas modificaciones ha perdurado hasta hoy, desarrollado primero por el RDU de 1978, pasando luego al Texto Refundido de la Ley del Suelo de 1992 y, finalmente, a la legislación autonómica, que ha incorporado algunas novedades en cuanto a las medidas de protección de la legalidad urbanística, incrementándolas o perfeccionándolas. De acuerdo con el mismo, se engloban es esta actividad de protección en primer lugar las medidas preventivas, dirigidas a evitar que se consoliden las actuaciones ilegales realizadas, dada la dificultad de revertir alteraciones afianzadas en el tiempo, y, en segundo lugar, comprende también tanto las concretas medidas de restauración del orden jurídico infringido por la actuación ilícita y la reposición de la realidad física alterada o trasformada ${ }^{30}$, como la imposición de las correspondientes sanciones a sus responsables.

Para el entendimiento del sistema, se debe partir de que una de las tradicionales actuaciones dirigidas a la garantía de la legalidad urbanística es aquella consistente en controlar a priori y exigir el cumplimiento de las normas urbanísticas y el planeamiento, sometiendo a previa licencia o autorización cualquier uso o utilización del suelo, como competencia histórica del municipio ${ }^{31}$-desde la Ley del Suelo de 1956 y como ahora se recoge en la legislación autonómica para todos los actos de uso, transformación y edificación del suelo, subsuelo y vuelo, como hemos señalado-, modo de intervención que, en lo que nos ocupa, hay que contemplar junto con las órdenes de

30 En este sentido, J.M. Arredondo Gutiérrez, Las infracciones urbanísticas, Granada, 1995, pp. 59 y L. Parejo Alfonso, La disciplina urbanística, op. cit. (cita 19), pp. 31-32.

31 Como señalan E. García de Enterría y L. Parejo Alfonso, Lecciones de Derecho Urbanístico, Madrid, 1991, p. 649, la licencia es la más característica de la competencias urbanísticas municipales. 
ejecución frente al incumplimiento de los deberes urbanísticos, concreción de lo previsto en el artículo 84.1 de la LRBRL. Por consiguiente, frente cualquier actuación en trance de realización o ya realizada sin contar con dichos títulos o contraviniéndolos, es posible una intervención a posteriori por la Administración competente, que deberá utilizar las medidas a su disposición, según la correspondiente previsión legislativa, tendentes a proteger la legalidad urbanística.

En este sentido, la adopción de las medidas de restauración del orden urbanístico infringido es de carácter imperativo, es una competencia irrenunciable y de inexcusable ejercicio por la Administración correspondiente. Presente dicha obligatoriedad en la anterior legislación estatal, actualmente se viene a disponer comúnmente en la legislación autonómica, tras haber sido reafirmada por el Tribunal Supremo, en el sentido de que la Administración no tiene la capacidad de optar. Así según su Sentencia de 4 febrero 1992, "ante el problema de una posible infracción administrativa, en general, y muy especialmente ante una de naturaleza urbanística, la Administración no tiene opciones, puesto que la simple sospecha de encubridora de cualquiera de ellas, no sólo representa una dejación de sus deberes de orden público, sino hasta motivo de reprobación por la ciudadanía de carácter ético-político». Por consiguiente, ante actuaciones de cualquier tipo, no sólo la ejecución de obras, realizadas sin haber obtenido con carácter previo la preceptiva autorización o que no traigan causa de una orden de ejecución, o que se realicen en contra de sus determinaciones, la Administración competente está obligada a reaccionar paralizando la alteración en la realidad física que comporta dicha actuación y reconduciéndola a la legalidad, según sea el caso.

De tal modo, ni la incoación de un procedimiento sancionador por la actuación ilícita ni la imposición de la correspondiente sanción y su cumplimiento exoneran a la Administración de su deber de adoptar las medidas tendentes a la restauración del orden urbanístico infringido ${ }^{32}$. Las sanciones pueden imponerse por aquella actuación con independencia de dichas medidas, ya que persiguen fines diferentes y tienen distinta naturaleza -aunque pueden adoptarse ambas en un único procedimiento-. Por ello mismo, también son independientes de la eventual sanción penal a la que den lugar esos mismos hechos por constituir un delito, de modo que la tramitación de un proceso de este tipo tampoco obsta apara que la Administración competente lleve a cabo las correspondientes medidas de protección de la legalidad urbanística. Por lo demás, ante la confusiones que se ha dado en ocasiones, la diferencia entre la adopción de medidas de protección de la legalidad urbanística y la actuación del régimen sancionador, se ha venido manteniendo en la jurisprudencia de un modo continuo (por todas, Sentencias del Tribunal Supremo de 3 de octubre de 1991 y 14 marzo 1995), al señalar que el procedimiento de restauración de la legalidad urbanística no

32 Su obligatoriedad e independencia de las eventuales sanciones ya se establecía en el RDU (artículo 52), por el que “en ningún caso podrá la Administración dejar de adoptar las medidas tendentes a reponer los bienes afectados al estado anterior a la producción de la situación ilegal. Las sanciones por las infracciones urbanísticas que se aprecien se impondrán con independencia de dichas medidas". 
es de naturaleza sancionadora propiamente dicha, teniendo por finalidad esencial la restauración del orden urbanístico conculcado ${ }^{33}$.

Asimismo, tampoco se dejarán de aplicar por la posible transmisión de los bienes sobre los que se ha producido la actuación. En este sentido se pronuncia el Tribunal Supremo en su Sentencia de 29 de enero de 1996, recogiendo el principio general de inmodificabilidad de la situación urbanística de los terrenos, ajena a las transmisiones de los mismos, y donde señala que, habitualmente, dicho principio se desenfoca desde el momento en que las partes lo contemplan bajo la perspectiva civil, con frecuentes y erróneas apelaciones al principio registral del tercer adquirente de buena fe. La respuesta para el Tribunal es clara, ya que en Derecho Urbanístico la figura del tercero de buena fe no juega, ya que no rigen criterios subjetivos, sino materiales y objetivos, como salvaguardia de los intereses generales y de orden público (Sentencia de 28 de noviembre de 1984). De tal modo, «el cambio de propietario debe resultar intrascendente y el adquirente ha de quedar subrogado en la posición jurídica del transmitente» (Sentencia de 8 noviembre 1990), pues «la medida de restauración del orden urbanístico alterado es de naturaleza real y no personal, como lo son las sanciones a imponer a los responsables [...], siendo así que en este proceso no se dilucida sanción alguna» (Sentencia de 31 enero 1995).

Las medidas de protección de la legalidad urbanística se deberán adoptar de ordinario por la Administración municipal, al ser de su tradicional competencia, como antes hemos tratado. En la organización municipal, normalmente es el alcalde quien tiene atribuidas esas funciones en la generalidad de las normas autonómicas, pues, no en balde, es a quien corresponde otorgar licencia ${ }^{34} y$ a quien se atribuyen las que no correspondan a otros órganos, según la cláusula residual del artículo 21.1.s) LRBRL. Ello no quiere decir que no puedan intervenir otros órganos del Ayuntamiento en algún momento de la actuación disciplinaria, pues su potestad de autoorganización (artículo 4.a LRBRL) permite esa posibilidad. Igualmente, en ocasiones para realizar esta función se han creado consorcios entre las Administraciones autonómicas y los municipios que voluntariamente han querido integrarse, como la Agencia de Protección del Medio Urbano y Natural de Canarias, o la Agencia de Protección de la Legalidad Urbanística de Galicia, o entre municipios solamente, como el Consorcio para la Protección de la Legalidad Urbanística en el Suelo Rústico de la Isla de Menorca35.

33 A la confusión de ambos regímenes ha contribuido, según L. Parejo Alfonso, La disciplina urbanística, op. cit. (cita 19), p. 28 y ss., que a partir de la Ley del Suelo de 1975 la infracción urbanística se entendiera en sentido amplio y pasara a ocupar un posición central en el juego de todos los mecanismos de reacción frente a la conculcación del orden urbanístico, rebasando su función definitoria del ilícito urbanístico a efectos de su represión a través de la potestad sancionadora.

34 Por ello, como señala F. Castillo Blanco, Régimen jurídico de las actuaciones urbanísticas sin título jurídico autorizante, Cizur Menor, 2006, p. 151, es posible que en los municipios de gran población corresponda a la Junta de Gobierno Local, al ser la competente para otorgar las licencias (artículo 121 LBRL).

35 Para E. Desdentado Daroca, “El control de la legalidad urbanística ¿Qué legalidad?, op. cit. (cita 15), p. 123, la creación de estas figuras supone un paso adelante, pero claramente insuficiente, ya que la cuestión no se resuelve creando un cauce alternativo y voluntario para la gestión de las potestades de la disciplina 
Es evidente que con ello se puede solventar en alguna medida uno de los recurrentes problemas de la disciplina urbanística, sustituyendo en su ejercicio a unos órganos que se caracterizan precisamente por su cercanía a los vecinos y evitando así las dificultades que en este orden ello comportaba en no pocas ocasiones.

No obstante, en algunos casos puede ser también la Administración autonómica la que adopte las correspondientes medidas de protección de la legalidad urbanística, bien por tener competencias sobre la materia, bien por subrogación. En el primer supuesto, así ocurre cuando se precisen otras autorizaciones diferentes de la licencia y lo determine la legislación autonómica, por ejemplo en actuaciones sobre suelo no urbanizable ${ }^{36}$ o respecto a usos del suelo que afecten al orden jurídico supramunicipal37. En el segundo supuesto, como también se preveía en el régimen anterior, la normativa autonómica recoge la posibilidad se sustitución en los casos en que, requerido el Ayuntamiento de actuación, no adopte el correspondiente acto en el plazo establecido (generalmente de un mes, aunque en ocasiones menor) ${ }^{38}$. Esta posibilidad ha de ser interpretada de modo restrictivo, como resulta de la ya citada Sentencia del Tribunal Constitucional 11/1999, en su examen del artículo 60 LRBRL, ya que este precepto, señala, se refiere a casos de incumplimiento de obligaciones legales que no se substancian en actos o acuerdos antijurídicos, sino en la mera y simple inactividad o parálisis funcional como hecho. Por consiguiente, podrá sustituirse o subrogarse en casos de inactividad municipal frente a actuaciones contrarias al ordenamiento urbanístico, pero no si estas responden a licencias u órdenes de ejecución ilegales ${ }^{39}$. En cualquier caso, según determina el artículo 44 del Texto Refundido de la Ley del Suelo de 2008, en estos supuestos, las decisiones que adoptaren los órganos autonómicos mediante subrogación se considerarán como actos del Ayuntamiento titular, a los solos efectos de los recursos admisibles. Se trata, en consecuencia, de otra previsión destinada también a paliar la problemática del incumplimiento de su obligación de reaccionar por la Administración municipal.

Por lo demás, recogiendo el sistema estatal e introduciendo algunas especialidades, la legislación autonómica estructura un procedimiento que puede desarrollase en diversas fases, según el supuesto contemplado, y que van desde la comprobación

urbanística, sino mediante una completa reorganización de la competencia que realmente responda a la eficaz satisfacción de los intereses generales y los objetivos que persigue el Derecho Urbanístico.

36 Así se prevé, por ejemplo, en la Ley Urbanística Valenciana (artículo 222), cuando en suelo no urbanizable se estén llevando a cabo actos de uso o edificación del suelo sin autorización urbanística autonómica, cuando ésta sea preceptiva, o sin ajustarse a sus determinaciones, y también en la Ley de Ordenación Territorial y Régimen Urbanístico del Suelo de Cantabria (artículo 115).

37 Como se dispone, por ejemplo, en la Ley de Urbanismo de Castilla y León (artículo 367).

38 Así se establece con carácter general en la normativa autonómica (recogida en cita 25), como, por ejemplo, en Andalucía, Asturias, Baleares, Cantabria, Extremadura, Galicia, La Rioja, País Vasco o la Comunidad Valenciana.

39 Para L. Parejo Alfonso, La disciplina urbanística, op. cit. (cita 19), p. 53, la sustitución autonómica no comporta juicio o control de legalidad alguno de la conducta municipal, sino exclusivamente un acto de comprobación de una circunstancia fáctica, y sobre la base de este acto de comprobación, la medida autonómica se produce ya en ejercicio de un competencia propia de la Comunidad Autónoma. 
de la actuación realizada y, en su caso, el requerimiento para su legalización, hasta la adopción de medidas para la restauración de la realidad física transformada, incluyendo la demolición de lo construido, una de las cuestiones más controvertidas ${ }^{40}$.

\section{Supuestos de actuaciones sin licencia ni orden de ejecución o en contra de sus determinaciones}

La temporalidad es el dato de referencia para determinar qué medidas adoptar, atendiendo a si la actuación ya ha finalizado o no lo ha hecho todavía, o si han pasado más de cuatro años o no desde su terminación, pues la posibilidad del ejercicio de la acción de restauración de la legalidad está limitada en el tiempo. Junto a ello, deberá considerarse si las actuaciones realizadas o en curso de realización (denominadas en ocasiones actuaciones clandestinas, como en las leyes de Castilla-La Mancha y de Extremadura) pueden ser legalizables o no, en función de la normativa urbanística aplicable y del planeamiento.

\section{A) Actuaciones en curso de ejecución}

\section{a) Inicio del expediente y adopción de medidas preventivas: requerimientos de suspensión y de legalización}

Una vez realizadas las necesarias comprobaciones, dirigidas a acreditar el hecho de que se están realizando actuaciones urbanísticas sin título o sin ajustarse a las condiciones del otorgado, la Administración resolverá en dos diferentes sentidos, en un procedimiento sumario y de contenido limitado que podrá finalizar adoptándose diversos acuerdos, según la situación, ya que se dirige a comprobar el ajuste de la actuación a la legalidad o a la licencia. Por un lado, dispondrá la adopción de las medidas cautelares que se consideren pertinentes, y con carácter fundamental la suspensión inmediata de las obras o el cese del uso en curso de ejecución o desarrollo, con lo que se pretende congelar las actuaciones en el estado en que se encuentren, con el fin de impedir una consolidación del estado de cosas que, en su caso, haría más gravosa la resolución final. Por otro, requerirá a su responsable para que legalice dichas actuaciones. Como una medida complementaria, y poniendo de relevancia la importancia de la colaboración de otras instancias en la salvaguarda de la legalidad urbanística, el artículo 51.2 del Texto Refundido de la Ley del Suelo de 2008 dispone que será inscribible en el Registro de la Propiedad la incoación de expediente sobre disciplina urbanística, de modo que se hará constar mediante anotación preventiva ${ }^{41}$.

40 Que últimamente ha evidenciado I. Rodríguez Fernández, “Demolición de obras ilegales, restablecimiento de la legalidad y tutela judicial efectiva. Reflexiones a propósito de la Sentencia del Tribunal Constitucional 22/209, de 26 de marzo", Revista General de Derecho Administrativo, n. 22, 2009, p. 1-48.

41 Estos aspectos se desarrollaron por medio del Real Decreto 1093/1997, de 4 de julio, por el que se aprueban las normas complementarias al Reglamento para la ejecución de la Ley Hipotecaria sobre inscripción en el Registro de la Propiedad de actos de naturaleza urbanística. 
En cuanto a la referida medida cautelar, su adopción forma parte de las primeras actuaciones del expediente, y consistirá en la suspensión sólo de la parte de la actuación en la que concurra la ilegalidad, pudiendo continuar en el resto, por lo que siempre deberá adecuarse a la concreta situación ${ }^{42}$, debiendo comunicarse igualmente al Registro de la Propiedad para su constancia, según viene especificando en ocasiones la legislación autonómica. Asimismo, se pueden adoptar también otras medidas preventivas, según prevé dicha legislación, como la suspensión de suministros (energía eléctrica, agua, gas y telefonía), o el precintado de máquinas, de accesos y de obras e instalaciones, la retirada de materiales, etc. El incumplimiento por parte del interesado de la orden de suspensión, que es una resolución autónoma y por ello impugnable, podrá dar lugar a la imposición de multas coercitivas o a otras medidas de ejecución forzosa.

Según se dispone en la legislación autonómica, dicha orden de suspensión podrá realizarse, indistintamente, al promotor, al propietario, al responsable del acto o, en su defecto, a cualquier persona que se encuentre en el lugar de ejecución, realización o desarrollo, y esté relacionada con el mismo. En todo caso, por su carácter, no se requiere la audiencia al interesado, ya que su función queda cubierta por otras actuaciones posteriores, como ha precisado numerosa jurisprudencia (por ejemplo, Sentencias del Tribunal Supremo de 27 marzo de 1987, de 3 de octubre de 1988, de 21 de abril de 1992, y de 13 de noviembre de 1992) ${ }^{43}$.

Respecto al requerimiento de legalización, se trata de que el responsable de las actuaciones cumpla la carga jurídica de solicitar la correspondiente licencia (Sentencias del Tribunal Supremo de 13 de diciembre de 1984, y de 7 de febrero de 1990), constituyendo tal requerimiento el requisito necesario y suficiente para ulteriores actuaciones administrativas. Al respecto, tampoco es preciso dar audiencia del interesado, pues, como señala la Sentencias del Tribunal Supremo de 3 de octubre de 1988, el requerimiento previo cumple no sólo las funciones habilitadoras de una legalización, sino también las generales del trámite de audiencia. Con carácter general, se otorga igual plazo que para solicitar la licencia o, en su caso, solicitar la modificación de la misma, es decir, dos meses -aunque alguna legislación autonómica reduce ese plazo a un mes, como en el País Vasco, o lo amplía a tres meses, como en Canarias, Galicia o Castilla y León-. Si, transcurrido el plazo conferido, el interesado no hubiere solicitado la licencia o la autorización correspondiente, la Administración acordará las medidas de restauración de la legalidad urbanística vulnerada.

En algunos casos, se establece una especialidad para las actuaciones que, contando con licencia u orden de ejecución, se están realizando sin ajustarse a sus condi-

42 Como indica L. Parejo Alfonso, La disciplina urbanística, op. cit. (cita 19), p. 45, la suspensión de la actuación no es una medida cautelar de contenido único y rígido, debiendo adecuarse éstas a las características que presente el supuesto de hecho concreto, como exigen los principios generales de congruencia y proporcionalidad.

43 Aun así, en ocasiones se prevé un trámite de audiencia tras la suspensión provisional, como en el Texto refundido de la Ley de Urbanismo de Cataluña (artículo 197). 
ciones, como se hace en la legislación de la Comunidad Valenciana, de Asturias y de Baleares. En estos supuestos, se requerirá a su responsable (promotor, constructor y técnico director) para que ajuste las actuaciones a ellas, una vez señaladas las anomalías observadas y concedido un breve plazo (normalmente de diez días) para aducir la concordancia de las obras con el contenido de la licencia u orden de ejecución. La falta de contestación dentro de dicho plazo implica aceptación de las irregularidades señaladas, por lo que se acordará de modo inmediato las medidas cautelares mencionadas. Si las estiman conformes a la misma, se realizará conjuntamente con los servicios municipales su examen in situ, tras lo que se resolverá, permitiendo la prosecución de la actividad o especificando un plazo para su adecuación a las condiciones de la licencia, vencido el cual sin que ésta se produzca tendrá lugar la adopción de las correspondientes medidas cautelares.

Por lo demás, cabe indicar que en algunos supuestos se puede actuar sin realizar las actuaciones mencionadas, cuando existe una manifiesta ilegalidad de la actuación realizada, ya que entonces puede la Administración proceder directamente a la adopción de las pertinentes medidas de restauración urbanística, una vez de han acordado las necesarias medidas cautelares ${ }^{44}$.

\section{b) Legalización de actuaciones y medidas de restitución}

La determinación de si se trata de una actuación ilegalizable o si es susceptible de legalizarse, se resuelve en el mismo expediente, con el examen de la solicitud de licencia y la documentación que ha de acompañarla ${ }^{45}$, tras lo que se decidirá sobre su otorgamiento o su denegación. Ha de tenerse en cuenta que entre las características de la licencia se encuentra su carácter reglado, de forma que se deberá otorgar la licencia o denegarla según que la actividad u obra proyectada cumpla o no la legislación urbanística y se acomode a los instrumentos del planeamiento, al ser su fin la comprobación de la adecuación entre ambas. Por consiguiente, en caso de que se dé esa adecuación, la licencia tendrá que otorgarse o modificarse. Al respecto, puede darse la circunstancia de un cambio de planeamiento durante la tramitación del procedimiento, ante lo que la legislación urbanística que lo prevé (como la de Aragón o La Rioja) aplica el principio de norma más favorable, como venía haciendo la jurisprudencia (por ejemplo, la Sentencia del Tribunal Supremo de 27 de noviembre de 1998).

En cambio, si no se puede legalizar, el único modo de proteger la legalidad urbanística consiste en reponer las cosas a su situación anterior, lo que implica restablecer la realidad física trasformada por aquella actuación e impedir una utilización o uso no

44 Así se prevé, por ejemplo, en la Ley de Ordenación Urbanística de Andalucía (artículo 183.1) para las obras que sean manifiestamente incompatibles con la ordenación urbanística, o en el Texto refundido de la Ley de Urbanismo de Cataluña (artículo 197.2) para actuaciones manifiestamente ilegalizables.

45 Lo que también se ha denominado proyecto de legalización, como en la Ley del Suelo y Ordenación Territorial de Extremadura (artículo 193.2). 
acorde con dicha legalidad. Las medidas de restauración deberán adaptarse al supuesto de hecho concreto, ponderando su adecuación con la finalidad de interés público que se persigue y no debiendo ir más allá de lo razonable, puesto que su adopción está informada por los principios de proporcionalidad y congruencia ${ }^{46}$, como precisamente se ha venido estableciendo en la normativa local. Así, como decía el artículo 6 del Reglamento de Servicios de las Corporaciones Locales de 1955, el contenido de los actos de intervención de ser congruente con los motivos y fines que los justifiquen, como luego recogería el artículo 84.2 LRBRL. Precisamente, dada la conflictividad muchas veces presente en estos casos, en diversas ocasiones la jurisprudencia ha apelado al principio de proporcionalidad en la adopción de medidas de restauración de la legalidad urbanística, señalando que, además de operar con carácter ordinario, en aquellos casos en los que el ordenamiento jurídico admite la posibilidad de elegir uno entre varios medios utilizables, también lo hace, ya con carácter excepcional y en conexión con los principios de buena fe y equidad, en los supuestos en los que aun existiendo en principio un único medio éste resulta a todas luces inadecuado y excesivo en relación con las características del caso contemplado (Sentencia del Tribunal Supremo de 18 febrero 1992 $)^{47}$.

Con la necesaria observancia de tales principios, el ejercicio de las potestades para adoptar las medidas de protección de la legalidad urbanística es de carácter esencialmente reglado, ya que están predeterminadas en la legislación autonómica para casa supuesto ${ }^{48}$, con el fin de devolver físicamente los terrenos, edificaciones o usos al estado anterior a la vulneración producida. De tal modo, y sin perjuicio de concreciones o especialidades previstas en esa legislación, con carácter general se dispone que, tratándose de obras de edificación, las operaciones de restauración consistirán en la demolición de las edificaciones realizadas ilegalmente -sólo cuando no sea posible otra cosa y realizada estrictamente. En los casos de demolición indebida, la restauración consistirá en la reconstrucción de lo demolido, cuando ello resulte procedente. En el supuesto de parcelaciones ilegales, las operaciones de restauración consistirán en la reagrupación de las parcelas, la cual, según los casos, podrá venir acompañada de la roturación de caminos, desmonte o desmantelamiento de servicios, demolición de vallados y cualesquiera otras que resulten necesarias a tal fin. En

46 Al respecto, entiende F. Castillo Blanco, Régimen jurídico de las actuaciones urbanísticas sin título jurídico autorizante, op. cit. (cita 32), pp. 94-95, que el principio de congruencia ha de traducirse en estos casos en un conducta administrativa tendente a buscar la solución adecuada para alcanzar los fines que justifican la actividad de intervención y acorde con los intereses generales a que sirve el objeto de la actividad.

47 En este sentido, en su Sentencia de 10 mayo 1995, dice que debe operar en todos aquellos casos en que el ordenamiento jurídico admite alguna otra posibilidad legal de evitar tan drástica medida como es la demolición de todo un edificio, como puede serlo la legalización de esa actuación, si ello es permitido por la legislación urbanística. También se ha apreciado la desproporción de la demolición en casos desajustes mínimos de la construcción con la normativa urbanística (Sentencia de 26 de noviembre de 1990).

48 Aunque, como señala F. Castillo Blanco, Régimen jurídico de las actuaciones urbanísticas sin título jurídico autorizante, op. cit. (cita 32), p. 75, esa normativa ha matizado posteriormente dicha caracterización parcialmente, de modo que en base, precisamente al principio de proporcionalidad y mediante la in306 troducción de conceptos jurídicos indeterminados, admite en ciertos supuestos la legalización de actuacio- 
los casos de uso o utilización indebida, consistirá en la orden de cese definitivo de la actividad. Además, complementariamente, pueden acordarse otros extremos, como el cese del suministro de agua, de energía eléctrica, gas y telefonía o la inhabilitación de accesos. En cualquier caso, y a los efectos antes mencionados, cuando corresponda deberá procederse a la anotación de la resolución administrativa ordenando la restauración de la legalidad infringida en el Registro de la Propiedad, de modo que la anotación que se cancelará cuando se haya restaurado el orden infringido.

La medida de restauración que corresponda se realizará a costa del interesado, concediéndole un plazo para su ejecución ${ }^{49}$. El incumplimiento de la orden de restauración dará lugar a la adopción de las medidas de ejecución forzosa, como las multas coercitivas para lograr la ejecución por el sujeto obligado de las medidas de restauración, quizás la medida más efectiva, la ejecución subsidiaria a costa del interesado, lo que se deberá acordar tras la última multa coercitiva impuesta, o la utilización de cualquier otros medios previstos en el ordenamiento jurídico ${ }^{50}$. Hay que señalar, no obstante, que esa ejecución en no pocas ocasiones no se llega a realizar nunca, dado que, tras el pertinente recurso judicial y sentencia confirmatoria, una modificación del planeamiento puede legalizar aquella situación, lo que ha llevado a que la jurisprudencia haya establecido una serie de límites a esa práctica51.

\section{B) Actuaciones totalmente terminadas y plazo de reacción}

La cuestión de la determinación del momento en que han finalizado las actuaciones contrarias al orden urbanístico -que no se plantea en los supuestos de usos indebidos, pues si ya han finalizado no se están realizado ${ }^{52}$ - ha sido resuelto por la legislación autonómica de manera similar a como lo había venido haciendo la jurisprudencia.

Por un lado, en los supuestos de actuaciones que cuentan con licencia u orden de ejecución pero se han apartado de sus determinaciones, la finalización se referirá

49 En otras ocasiones se establecen medidas de incentivación, como en el Texto Refundido de Canarias, con reducción de la multa por restablecimiento del orden jurídico perturbado (artículo 182).

50 A este respecto, el artículo 45 del Texto Refundido de la Ley del Suelo de 2008 dispone que los Ayuntamientos podrán utilizar la ejecución forzosa y la vía de apremio para exigir el cumplimiento de sus deberes a los propietarios, individuales o asociados, y a los promotores de actuaciones de transformación urbanística, y que los procedimientos de ejecución y apremio se dirigirán ante todo contra los bienes de las personas que no hubieren cumplido sus obligaciones, y sólo en caso de insolvencia, frente a la asociación administrativa de propietarios.

51 Véase al respecto I. Rodríguez Fernández, “Demolición de obras ilegales, restablecimiento de la legalidad y tutela judicial efectiva. Reflexiones a propósito de la Sentencia del Tribunal Constitucional 22/209, de 26 de marzo", op. cit. (cita 38), pp. 17 y ss., que se refiere también al fenómeno generalizado de hostilidad municipal al cumplimiento de los fallos que acuerdan la demolición, a los subterfugios de una Administración renuente a ello.

52 Así lo ha señalado L. Parejo Alfonso, La disciplina urbanística, op. cit. (cita 19), p. 68, pues el uso no cesa o finaliza sin que lo haga también la transgresión, por lo que a partir de ese momento no necesita reacción administrativa. 
a un acto formal que la implique, pues su apariencia es de normalidad. Por otro, en cuanto a la actuaciones sin licencia u orden de ejecución, normalmente se presume que están totalmente terminadas cuando quedan dispuestas para servir al fin previsto sin necesidad de ninguna actividad material posterior referida a la propia obra, o cuando así lo reconozca de oficio la autoridad que incoe el expediente. No cuenta, por consiguiente, desde que la Administración tuviera conocimiento de los hechos, aunque será ésta la que determinará el momento de la «total terminación» de las obras ${ }^{53}$, mediante los correspondientes informes de sus servicios técnicos, que gozan de la presunción de objetividad y certeza establecida en el artículo 137 LRJ-PAC. Por ello, en caso de desacuerdo, corresponderá al responsable de las mismas desvirtuar la conclusión técnica administrativa, acreditando cuándo se ha producido dicha terminación. No en balde, ha sido este quien voluntariamente se ha colocado en una situación de clandestinidad en la realización de unas obras y que por tanto ha creado la dificultad para el conocimiento del dies a quo (Sentencia del Tribunal Supremo de 5 de junio de 1991).

A partir del momento de dicha finalización, se establece un plazo de cuatro años en que es posible la reacción administrativa, de modo que, una vez ha transcurrido el mismo sin que la Administración correspondiente haya actuado, no podrá requerir de legalización ni, en su caso, proceder a la reposición de la realidad física alterada, si no fuesen legalizables. Ello por cuanto se ha venido considerando que se trata de un plazo de caducidad y no de prescripción, de modo que su cómputo no podrá interrumpirse y sólo queda enervado por la efectiva puesta en marcha de las medidas de restauración de la legalidad urbanística. Que se trata de un plazo de caducidad y no de prescripción, se ha sostenido en numerosas ocasiones por la jurisprudencia, señalando de manera constante que resulta inadecuado hablar de prescripción y sí correcto de caducidad de la acción administrativa o de presupuesto habilitante de la reacción (por todas, Sentencias del Tribunal Supremo de 5 de junio de 1991, de 22 de enero de 1992 o de 14 de marzo de 1995). En algunas leyes autonómicas ese plazo se amplía, como a ocho años en la Ley de disciplina urbanística de Baleares (artículo 65), o a seis años en el Texto refundido de la Ley de Urbanismo de Cataluña (artículo 219) y en la Ley de Ordenación Urbanística y Protección del Medio Rural de Galicia (artículo 210). No obstante, algunas normas autonómicas lo califican como plazo de prescripción (por ejemplo, la Ley Urbanística Valenciana o el Texto refundido de la Ley de Urbanismo de Cataluña), opción que ha sido apoyada en ocasiones por la doctrina, al considerar que no hay ninguna razón jurídicopública para considerar que el plazo es de caducidad, aconsejando la lógica jurídica lo contrario, de modo que, salvo que la ley disponga que se trata expresamente de un plazo de caducidad, debe considerarse como un plazo de prescripción ${ }^{54}$.

Por lo demás, con el fin de preservar especialmente determinados valores, con carácter general se establece que el plazo mencionado no será de aplicación en los

53 Lo que lógicamente comporta la instalación de las puertas, ventanas y elementos de acabado interior y exterior, según la Sentencia del Tribunal Supremo de 13 julio de 1985.

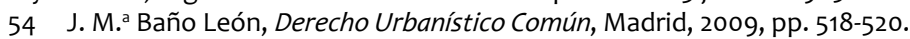


supuestos de actuaciones que se hubiesen ejecutado sobre terrenos o edificaciones de especiales características. La legislación autonómica procede en cada caso a relacionar estos supuestos, incluyendo, por ejemplo, los terrenos calificados en el planeamiento como zonas verdes, viales, suelo no urbanizable protegido, espacios libres o usos dotacionales públicos, terrenos o edificios que pertenezcan al dominio público, edificios que estén catalogados, suelos incluidos en la zona de influencia del litoral, etc.

Cuando no hubiese trascurrido dicho plazo en el caso de las actuaciones legalizables, se procederá como antes se ha indicado en orden al requerimiento de legalización o de ajuste de las obras a las condiciones de la licencia otorgada u orden de ejecución. Si el interesado no solicitara la licencia o autorización urbanística en el plazo conferido, o si la misma fuese denegada por ser su otorgamiento contrario a las prescripciones de la normativa urbanística, se procederá conforme lo ya señalado para la restauración de la legalidad urbanística. Si ya hubiese trascurrido ese plazo y se trata de actuaciones no legalizables, la solución será otra, pues esa situación no legaliza la actuación realizada, sino que determina que deben adoptarse otras medidas, de modo que las edificaciones quedarán sometidas al régimen de fuera de ordenación, con sus limitaciones, como ha venido establecido el Tribunal Supremo y recogen diversas normas autonómicas. Al respecto, se ha entendido que las obras quedan "asimiladas", que no sometidas, a la situación de fuera de ordenación, lo que implicaría que no hay más analogías con ese régimen, ya que su contenido se agota en posibilitar simplemente el uso de la construcción correspondiente, sin que, en vía de principio, sea factible su mejora, reforma, ampliación o conservación ${ }^{55}$, ya que las obras continúan siendo ilegales. Sin embrago, lo cierto es que en algunos casos se prevé que cualquier acto que implique reforma, ampliación o consolidación de estos edificios requerirá la previa aprobación de un proyecto de legalización, que contemplará el conjunto de medidas para la reducción o eliminación de su impacto, y que podrá aprobarse de oficio (como en las leyes del País Vasco y de Extremadura).

\section{Supuesto de actuaciones ilegales amparadas en una licencia u orden de ejecución}

Es posible que se las actuaciones realizadas o en curso de ejecución sean acordes con la licencia u orden de ejecución correspondiente, y que sean éstas las que, precisamente, vulneren el orden urbanístico en el momento de otorgarse o dictarse. La Administración que las ha dictado podrá reaccionar de diversos modos, según sea el caso, con la finalidad de privarla de efectos jurídicos para, seguidamente, proceder

55 En este sentido, L. Parejo Alfonso, La disciplina urbanística, op. cit. (cita 19), p. 69-70. Para J. M. ${ }^{\mathrm{a}}$ Baño León, Derecho Urbanístico Común, op. cit. (cita 52), p. 522, el eufemismo de la obra tolerada que se asimila a la situación de fuera de ordenación supone en la práctica su legalización, considerando que las obras que no cuentan con licencia y son contrarias a las determinaciones de la ordenación son ilegales y que esa situación no debería sanarse con el transcurso del tiempo. 
a adoptar las pertinentes medidas de restauración de la legalidad perturbada, sin perjuicio de que puedan adoptarse las medidas cautelares que se estimen necesarias. El camino a seguir dependerá de si se trata de actuaciones en curso de ejecución o que ya han finalizado, pues se tendrán que paralizar o revisar.

En el primer caso, la Administración viene a ejercitar una pretensión de anulación de la licencia en su día concedida, o de una orden de ejecución dictada, de manera que el acto objeto del recurso lo constituye el acuerdo de concesión de tal licencia u orden de ejecución. En la legislación urbanística estatal se preveía una vía concreta cuando se trataba de obras en ejecución así amparadas, lo que ha recogido generalmente de manera similar la legislación autonómica (realizándose en algunos casos remisiones a la legislación estatal supletoria, como en Cantabria, La Rioja o Castilla y León). En dicho sistema, el alcalde debe disponer la suspensión de los efectos de la licencia u orden de ejecución y, consiguientemente, la paralización inmediata de las obras iniciadas a su amparo, para, acto seguido (en el plazo de tres días generalmente, aunque a veces se establece en diez días, como en Madrid o Cantabria, o no se concreta, por lo que se aplicará el supletorio estatal), proceder a dar traslado directo de dicho acuerdo al órgano competente del orden jurisdiccional contencioso-administrativo, a los efectos previstos en el artículo 127 de la Ley 29/1998, de 13 de julio, reguladora de la Jurisdicción Contencioso-Administrativa. En este precepto se establece un procedimiento especial y sumario para los casos de suspensión administrativa previa de acuerdos, que finaliza con sentencia en la que se anulará o confirmará el acto, disponiendo lo que proceda en cuanto a la suspensión.

Por consiguiente, la competencia para suspender por regla general corresponde al alcalde, por lo que la Administración autonómica no puede decretar directamente la suspensión de los actos de ejecución, sino que, en su caso, habrá de impugnar la licencia municipal, previo requerimiento de anulación, o interponer directamente recurso contencioso administrativo, en los términos establecidos en la LRBRL. En este sentido, ha declarado en numerosas ocasiones el Tribunal Supremo, partiendo de la doctrina establecida por el Tribunal Constitucional (Sentencias 213/1988, de 11 noviembre y 259/1988, de 22 diciembre), que las Comunidades Autónomas carecen de competencia para suspender los acuerdos de las Corporaciones Locales en materia de urbanismo, como se establecía en el Texto refundido de la Ley del Suelo de 1976, por haberse suprimido su anterior potestad tras la promulgación de la LBRL, conforme a sus artículos 65 y 66 (por todas, Sentencia de 16 febrero 1993) ${ }^{56}$. A partir de ahí, en algunas ocasiones se regula su subrogación en caso de inactividad (Asturias, La Rioja y Canarias, por ejemplo).

Tanto en la legislación estatal como en gran parte de la autonómica, es necesario que para acordar la anulación se esté en presencia de una infracción urbanística gra-

56 Por ello, un difícil encaje en este sistema tiene la previsión de la Ley Urbanística Valencia de que cuando la obra o acción de que se trate ponga en peligro la integridad de espacios naturales protegidos o bienes de interés cultural, la autoridad autonómica procederá a su inmediata suspensión material, dando 310 cuenta de ello al Ayuntamiento y sin que haya lugar a la práctica de requerimiento. 
ve -quedando especificadas las infracciones de tal naturaleza legalmente- y, además, el carácter manifiesto de dicha infracción, de modo que cuando así se establezca, solamente este supuesto faculta al alcalde para directamente suspender los efectos de la autorización concedida (Sentencia del Tribunal Supremo de 16 mayo $1998)^{57}$. Por consiguiente, se exige que la infracción no se advierta de cualquier forma, sino, concretamente, de forma «manifiesta», concepto que ha sido reiteradamente delimitado por la jurisprudencia como patente, notorio o evidente, de manera que no exija su apreciación acudir a interpretaciones analógicas o a intrincados razonamientos jurídicos y que baste al respecto el simple enfrentamiento del acuerdo por el que se haya otorgado la licencia o impartido la orden con el texto literal de las normas incumplidas (Sentencias del Tribunal Supremo, de 16 de mayo de 1998 y de 1 de febrero de 2000, entre otras). No obstante, cabe también indicar que no se requiere siempre que se trate de infracción grave y manifiesta ${ }^{58}$.

En el otro supuesto, cuando se trate de actos que ampararan actuaciones ya finalizadas, dispone el artículo 46 del Texto Refundido de la Ley del Suelo de 2008 que las Entidades locales podrán revisar de oficio sus actos y acuerdos en materia de urbanismo con arreglo a lo dispuesto en la legislación de régimen jurídico de las Administraciones Públicas. Por consiguiente, serán las vías de los artículos 102 y 103 de la LRJ-PAC las que se deberán de utilizar, es decir, la revisión administrativa o revisión judicial previa declaración de lesividad, según los efectos del acto.

\section{EL RÉGIMEN SANCIONADOR URBANÍSTICO}

\section{La competencia sancionadora}

Como se ha señalado, la vulneración del ordenamiento jurídico urbanístico puede provocar dos tipos de consecuencias jurídicas, como son la ya vista adopción de medidas para la restauración del orden jurídico infringido y de la realidad física alterada o trasformada, y la imposición de sanciones, cuando la actuación además de ser ilegal ha sido objeto de la necesaria tipificación como infracción, operando conjuntamente ambos tipos de consecuencias cuando resultan procedentes (Sentencia del Tribunal Supremo de 18 febrero 1992). Así se ha venido estableciendo en la legislación estatal, y ha sido recogido por las Comunidades Autónomas que han establecido su propio régimen sancionador en urbanismo. Cuando lo han hecho, en gran parte reco-

57 Al respecto, para E. Desdentado Daroca, “El control de la legalidad urbanística ¿Qué legalidad?," op. cit. (cita 15), pp. 95-96, esta regulación específica tiene un carácter indudablemente restrictivo, pues limita las posibilidades de suspensión y anulación de las licencias en curso de ejecución a los casos de infracciones graves, manifiestas, patentes, dejando a los demás supuestos de irregularidad al margen de estas posibilidades, considerando que se debería posibilitar para esos otros supuestos que se ejerciera la potestad de revisión de oficio con la correspondiente suspensión de la licencia.

58 Por ejemplo el Texto refundido de la Ley de Urbanismo de Cataluña, lo establece para un contenido contrario a las determinaciones de la Ley, de los planes urbanísticos o de las ordenanzas urbanísticas municipales (artículo 200). 
gen y actualizan las previsiones del RDU, con algunas aportaciones novedosas, siendo normales las remisiones a la legislación estatal y la necesidad de suplir determinadas omisiones, al no contener una regulación detallada de la actividad sancionadora. Así, proceden a la atribución de la capacidad sancionadora, tipificando igualmente tanto las infracciones como las sanciones, al tiempo que se recogen todos los principios sustantivos del Derecho sancionador, partiendo de su finalidad de garantizar el efectivo cumplimiento del orden urbanístico.

De tal modo, como hemos tratado, recoge la atribución competencial tradicional por la que la imposición de las sanciones urbanísticas corresponde a los Ayuntamientos con carácter general, aunque se suele residenciar en el órgano autonómico correspondiente cuando la sanción de multa supera una determinada cantidad. Por lo demás, cabe reiterar lo ya dicho anteriormente, en el sentido de que pueden operar igualmente otras figuras, como las consorcios ya referidos, y que además la Administración autonómica también podrá intervenir en supuestos de subrogación o sustitución, cuando el municipio no ejerza sus funciones y también en supuestos especiales, de modo concurrente con el municipio. No en balde, en estos supuestos se presentan iguales dificultades para el ejercicio de la potestad municipal que en el anterior. A este respecto, el Tribunal Supremo, en su Sentencias de 2 y 10 noviembre 2005 señala que del artículo 25.2 d) LRBRL no se deduce que las competencias del municipio en materia de disciplina urbanística excluyan en todo caso cualquier intervención de las Comunidades Autónomas, pues aquéllas se ejercerán en los términos de las legislación del Estado y de las Comunidades Autónomas, que prevén la intervención del órgano autonómico competente en defecto de actuación del Ayuntamiento, tratándose de un simple control de legalidad que se ejerce sin contradecir el principio constitucional de autonomía. Como ya nos consta, en el supuesto de sustitución autonómica en las competencias municipales, se requerirá una comunicación previa al municipio para que adopte las medidas legales que corresponda, y sólo cuando mostrara inactividad o negligencia en el ejercicio de sus competencias de sanción de las infracciones urbanísticas -requiriéndose normalmente que sea grave y manifiesta y que existan específicos intereses supralocales afectados-, la Administración autonómica podrá asumir la competencia por sustitución, en los términos establecidos en el artículo 60 LRBRL. En cuanto a competencias autonómicas concurrentes, podrá venir determinada por el carácter de la infracción cometida y el tipo de suelo del que se trate (por ejemplo, cuando se trata de infracciones graves o muy graves cometidas en suelo no urbanizable, como dispone la Ley Urbanística Valenciana), dando participación en el expediente al Ayuntamiento en cuyo término municipal haya acontecido.

Por lo demás, una de las características del régimen sancionador urbanístico es que la reacción administrativa puede ser instada por cualquier persona, pues, no en balde, la acción pública ha sido tradicional en este ámbito, frente a otros sectores en los que después se ha posibilitado. Con ella, se permite que cualquier ciudadano, individual o colectivamente, y sin legitimación alguna, pueda requerir al órgano adminis-

312 trativo competente para que actúe y así lograr que se adopten medidas para prote- 
ger la legalidad urbanística y que se impongan las sanciones pertinentes ${ }^{59}$. Actualmente, el artículo 48 del Texto Refundido de la Ley del Suelo de 2008 dispone que será pública la acción para exigir ante los órganos administrativos y los Tribunales Contencioso-Administrativos la observancia de la legislación y demás instrumentos de ordenación territorial y urbanística, y que si dicha acción está motivada por la ejecución de obras que se consideren ilegales, podrá ejercitarse durante la ejecución de las mismas y hasta el transcurso de los plazos establecidos para la adopción de las medidas de protección de la legalidad urbanística. Por consiguiente, será el legítimo deseo de defensa de la legalidad urbanística lo que amparará a acción pública, debiéndose evitar que se haga un uso fraudulento de la misma y la instrumentalicen con el objeto de conseguir resultados que de otro modo no podrían obtener ${ }^{60}$. En cualquier caso, como dice la Sentencia del Tribunal Supremo de 22 de abril de 1988, no es posible encontrar abuso de derecho en la pretensión de que la actividad administrativa se acomode a la legalidad.

\section{Las infracciones urbanísticas y sus responsables}

En la potestad sancionadora en el campo urbanístico posee una trascendencia manifiesta el principio de legalidad consagrado en el artículo 25.1 de la Constitución, que, como ha señalado el Tribunal Constitucional (Sentencias 101/1988, de 8 junio, y $61 / 1990$, de 30 de marzo, entre otras) posee una doble vertiente, formal y material, consistentes en el principio de reserva de ley y en el principio de tipicidad, de modo que exige tanto la previa determinación de las infracciones y sus sanciones como que esa predeterminación se haga de una norma con rango legal suficiente, lo que se recoge en los artículos 127 y 129 LRJ-PAC. Por consiguiente, el principio de tipicidad constituye una de las garantías esenciales del sistema, por cuanto comprende la necesidad de que se predeterminen legalmente las conductas ilícitas y las sanciones correspondientes mediante conceptos jurídicos que permitan predecir con suficiente grado de certeza las conductas que constituyen una infracción y sanciones aplicables. Por tanto, la infracción urbanística debe estar determinada de forma clara, no cabiendo cláusulas generales o indeterminadas de infracción que permitan al órgano sancionador actuar con un excesivo arbitrio. Igualmente, las normas definidoras de infracciones y sanciones no serán susceptibles de aplicación analógica, puesto que este principio quebraría si se sancionaran conductas no tipificadas legalmente pero que se consideran análogas de las que sí lo están. Sin embargo, se ha sostenido que este principio debería ser entendido en este ámbito de modo flexible, pues la complejidad

59 Como dice L. Parejo Alfonso, La disciplina urbanística, op. cit. (cita 19), p. 25, la puesta en marcha del mecanismo represor no puede sustraerse a la colectividad, que es la directamente afectada por la trasgresión de la legalidad. Véase sobre la misma M. ${ }^{a}$ D. Rego Blanco, La acción popular en el Derecho Administrativo y en especial, en el urbanístico, Sevilla, 2005.

60 A este respecto, en laSentencia del Tribunal Supremo de 22 de enero de 1980 se declara que el ejercicio de la acción pública buscando exclusivamente el daño de un tercero y no el beneficio propio o de la colectividad, constituye un abuso de derecho. En este caso, será necesario que se den los supuestos que lo configuran, pesando la carga de su probanza sobre quien lo invoca (Sentencia de 4 de marzo de 1992). 
y casuística de la ordenación urbanística impide una tipificación muy concreta y pormenorizada, de modo que debería darse por buena la utilización de remisiones a la ordenación urbanística establecida en el planeamiento cuando sean estrictamente necesarias ${ }^{61}$, dado entrada, en su caso, a la colaboración municipal por medio de sus ordenanzas urbanísticas, pues se trata de una materia indudablemente de su interés, lo que justifica su intervención.

Tradicionalmente, las infracciones urbanísticas se han venido definiendo como las acciones u omisiones que vulneren las prescripciones contenidas en la legislación y el planeamiento urbanísticos, tipificadas y sancionadas en aquélla. A partir de ahí, hay diversas formas de tipificar los ilícitos urbanísticos, de modo que algunas normas autonómicas realizan una tipificación directa, detallando con precisión cada una de las conductas constitutivas de infracción (por ejemplo, en Aragón), algunas novedosas $^{62}$, mientras que otras optan también por una tipificación por remisión a otros preceptos o disposiciones (como en Galicia). Por lo demás, si bien en el RDU se clasificaban sólo en graves y leves, en la legislación autonómica se prevén también las infracciones muy graves, de acuerdo con lo establecido en el artículo 129 LRJ-PAC, distribuyendo los tipos antes previstos entre los de mayor gravedad.

Su exposición completa aquí no es útil ni sencilla, por cuanto existe una diversa tipificación en las normas autonómicas, por lo que simplemente haremos referencia a los supuestos ilícitos más comúnmente tipificados, y que habitualmente se corresponden con las obligaciones establecidas con carácter general por la legislación urbanística. En este sentido, suelen tener la consideración de infracciones muy graves las acciones y omisiones que constituyan incumplimiento de las normas urbanísticas relativas al uso del suelo y construcción que afecten a zonas verdes, espacios libres, dotaciones, equipamientos o al suelo no urbanizable protegido, así como las parcelaciones ilegales en suelo no urbanizable. Como infracciones graves se recogen habitualmente las acciones y omisiones que constituyan incumplimiento de las normas relativas a parcelaciones, aprovechamiento urbanístico, edificabilidad, uso del suelo, altura, volumen, situación de las edificaciones y ocupación permitida de la superficie de las parcelas, o la de edificación de éstas en exceso del aprovechamiento subjetivo sin haber cumplido las condiciones de gestión urbanística exigibles, y además el incumplimiento por el urbanizador de los compromisos asumidos con la Administración o los propietarios. Por su parte, las infracciones leves suelen ser las que no tienen carácter de graves o muy graves y, en todo caso, la ejecución de obras o instalaciones realizadas sin licencia y orden de ejecución cuando sean legalizables por ser conformes con el ordenamiento urbanístico. Se establecen asimismo unos diversos plazos de prescripción, que comenzará a computarse desde la fecha en que se hubiera cometido la infracción o, si ésta fuera desconocida, desde la fecha en que

61 L. Parejo Alfonso, La disciplina urbanística, op. cit. (cita 19), p. 23.

62 Y también algunas injustificadas, según entiende J. M. ${ }^{a}$ Baño León, Derecho Urbanístico Común, 314 op. cit. (cita 52), pp. 533-534, como las sanciones de conductas que implican incumplimientos de pactos de 
hubiera podido incoarse el procedimiento sancionador por aparecer signos exteriores que permitan conocer los hechos constitutivos de infracción, mientras que en las infracciones derivadas de una actividad continuada, la fecha inicial del cómputo será la de finalización de la actividad o la del último acto con el que la infracción se consu$\mathrm{ma}^{63}$, variando los plazos de unas Comunidades Autónomas a otras ${ }^{64}$.

En cuanto a los sujetos responsables, lo serán todas las personas físicas o jurídicas que incurran en infracción urbanística en sus conductas, obras, actuaciones o bien mediante el incumplimiento de sus obligaciones o de las órdenes de las que sean destinatarios. Como se dice en la Sentencia del Tribunal Supremo de 26 noviembre 1991, por virtud de la unidad sustancial del ius puniendi aquí han de aplicarse los principios penales, y más concretamente el principio de la personalidad de la pena que da lugar a que la responsabilidad haya de ser consecuencia de la participación en los hechos constitutivos de la infracción, no resultando viable sancionar a quien no ha cometido la infracción. Por tanto, que en el terreno sancionador no opera la subrogación que se da en los supuestos de protección de la legalidad urbanística.

Por consiguiente, en el caso de infracciones relativas a actos de ejecución de obras y construcciones y de uso del suelo, serán responsables el promotor, el constructor y el director o directores de la obra, considerándose como tales aquellos que así aparecen definidos en la Ley 38/1999, de 5 de noviembre, de Ordenación de la Edificación -se considerará también como promotor el propietario del suelo en el cual se cometa la infracción, salvo prueba en contrario-. Asimismo, se amplía el ámbito subjetivo de los responsables de infracción a quienes colaboran en alguna medida en su comisión, lo que en la legislación autonómica se recoge, con alguna especificación en ocasiones. Es el caso de las compañías suministradoras de servicios urbanísticos declarados esenciales, que serán responsables de las infracciones que se deriven del incumplimiento de sus obligaciones tipificadas en la ley urbanística correspondiente. Por su parte, las personas jurídicas serán sancionadas por las infracciones urbanísticas cometidas por sus órganos y agentes. Asimismo, también se suele contemplar los supuestos de responsabilidad en el caso de actuaciones contrarias al ordenamiento urbanístico amparadas en licencia u orden de ejecución

63 La prescripción de la infracción se interrumpe cuando se tenga conocimiento por el interesado de la incoación del correspondiente expediente sancionador o de la iniciación del expediente de protección de la legalidad urbanística. Ha precisado el Tribunal Supremo en su Sentencia de 14 febrero 1997 que no basta que la Administración incoe el expediente sancionador; es necesario, también, por razones obvias de seguridad jurídica y de justicia, que lo resuelva sin dilaciones ni interrupciones indebidas. Por ello la paralización del procedimiento sancionador por tiempo superior al establecido legalmente para que se produzca la prescripción debe determinar la nulidad de la sanción impuesta.

64 Siendo por lo general en las infracciones leves de un año, aunque también se prevé que sea de dos años (Extremadura, Galicia y País Vasco) y hasta de cuatro años (Madrid), o se reduce a seis meses en Navarra. Las prescripción de las infracciones oscila entre los dos años (Andalucía, Navarra y Canarias), tres años (Cantabria, Castilla-La Mancha y Extremadura), el plazo más común de cuatro años, y los seis años 6 (Galicia) o los ocho años (Baleares). Finalmente, las infracciones muy graves suelen ser de cuatro años, aunque en ocasiones es de cinco años (Castilla-La Mancha, Extremadura y País Vasco) o seis años (Cataluña), hasta llegar a lod siez años (Aragón) o los quince años (Galicia). 
ilegal, que alcanza a los funcionarios y miembros de los órganos que intervinieron en su otorgamiento.

En cualquier caso, no será posible la responsabilidad solidaria, ya que, como señala laSentencia del Tribunal Supremo de 2 de noviembre de 1992, el derecho sancionador está impregnado de los principios del derecho penal, y en el caso que nos ocupa "el principio de individualización de las penas es plenamente aplicable y plenamente contrario a la aplicación de solidaridad alguna, la que estaría en contra de lo dispuesto en el artículo 25 de la Constitución". A mayor abundamiento, el Tribunal Supremo ensentencia de fecha 16 de noviembre de 1998, señala que "la responsabilidad solidaria [... ] no puede penetrar en el ámbito del derecho sancionador porque, de lo contrario, se derrumbaría el fundamento del sistema punitivo, según el cual cada uno responde de sus propios actos, sin que quepa, con el fin de una más eficaz tutela de los intereses públicos, establecer responsabilidad alguna sancionable solidariamente por actos ajenos. Cuestión distinta es la posible tipificación de conductas que, conjuntamente por acción u omisión, puedan estimarse por la ley formal sancionables, o que ésta disponga diferentes formas de participación en el hecho tipificado como tal infracción y señale expresamente la sanción que a estas formas participativas corresponda, pero lo que no cabe es de imputación solidaria de responsabilidades punibles".

\section{Las sanciones urbanísticas. Tipología y extensión}

Las acciones u omisiones constitutivas de infracción urbanística darán lugar a la imposición de las correspondientes sanciones, previa la tramitación del procedimiento sancionador. El plazo para resolverlo varía en la legislación autonómica, siendo en unos casos de seis meses contado desde la fecha de su iniciación (Comunidad Valenciana, Aragón, Asturias o Navarra, entre otras) plazo ampliable, mientras que en otros se fija en un año (Extremadura, Galicia o Murcia, por ejemplo). Transcurrido el plazo máximo para resolver sin que se dictase resolución, se entenderá caducado el procedimiento, por lo que en el supuesto de que la infracción no hubiese prescrito, deberá iniciarse un nuevo procedimiento sancionador.

Como antes se ha indicado, el mandato de tipificación se desarrolla también en el momento de de atribuir a cada una de tales infracciones la sanción que le corresponde, por lo que no sólo la infracción, sino también la sanción que le corresponde ha de estar debidamente prevista en la ley, estableciendo la correlación entre una y otra. Por ello mismo, se prohíbe la interpretación o aplicación analógica, extensiva o inductiva de las normas definidoras de infracciones y sanciones administrativas, consecuencia inmediata del principio de interpretación estricta de los preceptos conformadores del Derecho sancionador (Sentencia del Tribunal Supremo de 21 de diciembre de 1982), puesto que la aplicación de criterios extensivos o analógicos, en el caso de ser utilizados, reconocerían a la Administración una facultad creadora de correctivos analógicos que pugnaría con el principio de seguridad jurídica y con las garantías del administrado

316 (entre otras, Sentencia del Tribunal Constitucional 142/1999, de 22 de julio). 
Las sanciones urbanísticas generalmente consisten en multas, tanto en la legislación estatal como en la autonómica. No obstante, se prevé también que pueda imponerse al infractor un impedimento temporal para realizar una determinada actividad o mantener determinadas relaciones jurídico-administrativas (como ser beneficiario de subvenciones, celebrar contratos con Administraciones públicas o ser urbanizador) ${ }^{65}$, la expropiación de terrenos o edificaciones, o el comiso del beneficio ilícito obtenido, por ejemplo. Algunas leyes califican estas consecuencias como sanciones a aplicar junto con la multa, mientras que otras hablan de sanciones accesorias $^{66} \mathrm{o}$ adicionales y algunas no califican estas consecuencias como sanción, pero afirman que están aparejadas a la sanción o las califican como medidas adicionales. Como una medida complementaria de las anteriores, el artículo 51.2 del Texto Refundido de la Ley del Suelo de 2008 dispone que será inscribibles en el Registro de la Propiedad la incoación de expediente que tengan por objeto el apremio administrativo para garantizar el cumplimiento de sanciones impuestas, de modo que se hará constar mediante anotación preventiva.

En el momento de determinar qué sanción corresponde a cada infracción, el resultado final dependerá de las diversas circunstancias concurrentes, en base a una serie de criterios que constituyen una garantía derivada del principio de proporcionalidad y que se deberán tener en cuenta de forma especial. Han sido recogidos de diverso modo por la legislación autonómica, pudiendo resaltar, por su coincidencia, que como criterios agravantes y atenuantes se atenderá primordialmente a la gravedad de la materia, a la entidad económica de los hechos constitutivos de la infracción, a su reiteración por parte de la persona responsable y al grado de culpabilidad de cada uno de los infractores.

A partir de ahí, el margen aplicativo en las cuantías de las multas que se establece en la legislación autonómica se basa en un sistema diferente al de la legislación estatal,

65 Algunas normas se refieren al supuesto concreto de infracciones relacionadas con la ejecución de obras urbanizadoras, caso en que se prevé la imposición de la sanción de inhabilitación por un período de varios años para la realización de este tipo de obras, como en la Ley del Suelo y Ordenación Territorial de Extremadura (artículo 199.3), la Ley de Ordenación del Territorio y de la Actividad Urbanística de Castilla-La Mancha (artículo 184.3), que inhabilita para ser urbanizador o desarrollar actividades de relevancia urbanística, y Ley de Ordenación Urbanística de Andalucía (artículo 209); o la prohibición de ejercicio del derecho de iniciativa para la atribución de la actividad de ejecución en unidades de actuación y de participación en cualquier otra forma en iniciativas o alternativas a éstas formuladas por propietarios o terceros, como en el Texto Refundido de las Leyes de Ordenación del Territorio de Canarias (artículo 204), o la Ley del Suelo de la Región de Murcia (artículo 242); o para asumir la condición de urbanizador. Estas medidas, por consiguiente, se impondrán sin perjuicio de la multa que, en su caso, corresponda. Ello puede ir acompañado de la inscripción en un Registro en el que constarán las resoluciones por las que se imponga la sanción de inhabilitación para asumir la condición de Urbanizador, a cuyo efecto los órganos administrativos que adopten dichas resoluciones deberán remitir copia de las mismas a la Administración autonómica que gestiona (Ley Urbanística Valenciana).

66 Es el caso de la Ley Foral de Ordenación del Territorio y Urbanismo (artículo 257), de la Ley de Urbanismo de Castilla y León (artículo 117.6), de la Ley de Ordenación territorial y Régimen Urbanístico del Suelo en Cantabria (artículo 222), o de la Ley de Ordenación Urbanística y Protección del Medio Rural de Galicia (artículo 221) 
que define el máximo y el mínimo de las multas no con relación a cantidades concretas y precisas, sino por medio de porcentajes sobre un específico valor (de la obra, de la edificación o de la actuación proyectada) fijado ad hoc para cada tipo de infracción urbanística, valor este que opera como base a la hora de concretar la sanción, sistema que parcialmente se contempla también en alguna Comunidad Autónoma (como el País Vasco $)^{67}$. En su fijación se mueven entre márgenes muy amplios, de lo que pueden resultar, en la práctica, cuantías muy diversas, lo que hace necesario una adecuada motivación de su determinación. A este respecto, el Tribunal Supremo ha venido señalando que la discrecionalidad que se otorga a la Administración en la imposición de sanciones dentro de los límites legalmente previstos, debe ser desarrollada ponderando en todo caso las circunstancias concurrentes, al objeto de alcanzar la necesaria y debida proporción entre los hechos imputados y la responsabilidad exigida, dado que toda sanción debe determinarse en congruencia con la entidad de la infracción cometida y según un criterio de proporcionalidad en relación con las circunstancias del hecho, proporcionalidad que constituye un principio normativo que se impone como un precepto más a la Administración y que reduce el ámbito de sus potestades sancionadoras (por todas, Sentencias de 18 de marzo y 24 de septiembre de 1996) ${ }^{68}$.

Asimismo, en el momento de la imposición de las sanciones económicas, se hacen jugar normalmente otras reglas, como en caso de concurrencia de infracciones, de modo que normalmente se sigue la que ya establecía el RDU, por el que ante dos infracciones con relación de causa a efecto, se impondrá sólo la sanción correspondiente a la más grave en su cuantía máxima (artículo 60). También se recoge el principio general del sistema por el que en ningún caso la infracción urbanística puede suponer un beneficio económico para el infractor, por lo que se establece que cuando el beneficio obtenido con la infracción sea superior a la multa, se incrementará ésta hasta alcanzar la totalidad de aquél, o que cuando la suma de la sanción impuesta y del coste de las actuaciones de reposición de los bienes y situaciones a su primitivo estado arrojase una cifra inferior a dicho beneficio, se incrementará la cuantía de la multa hasta alcanzar el valor del mismo. En cuanto a la prescripción de las sanciones, el cómputo del plazo se iniciará a partir del día siguiente al de la fecha de la notificación de la resolución sancionadora a los sancionados. Como en el caso de las infracciones, las previsiones son diferentes en cada Comunidad Autónoma ${ }^{69}$.

67 Como señala A. Carceller Fernández, Derecho urbanístico sancionador, Barcelona, 2004, p. 89, este sistema dificultaba la imposición de las sanciones, porque ese específico valor se prestaba a discusión y podía ser objeto de impugnación.

68 Por tanto, la discrecionalidad atribuida al establecer unos límites máximos y mínimos no puede interpretarse como libre arbitrio, sino como ejercicio de una actividad represora de conductas típicamente antijurídicas, donde el elemental principio de proporcionalidad entre la trascendencia del hecho y antecedentes del infractor, con su entidad económica, es de suyo principio informante del Ordenamiento Jurídico al cual deben ajustarse todos los actos de la Administración Pública; es por todo ello por lo que se supedita la concreción cuantitativa de la multa a expresos criterios derivados del referido principio de proporcionalidad cuales son gravedad de la materia, su importancia económica, la reiteración por parte de la persona responsable, el grado de culpabilidad de cada uno de los infractores (Sentencia del Tribunal Supremo de 29 marzo de 1982).

69 Así, generalmente, las sanciones leves prescriben en un año, aunque también se reduce el plazo 
Finalmente, hay que indicar que es también consustancial al sistema sancionador urbanístico la prohibición de la concurrencia de sanciones. Si bien en la etapa preconstitucional eran perfectamente compatibles e incluso independientes respecto a las penales frente a unos mismos hechos, por considerarse que eran ordenamientos distintos, el Tribunal Constitucional estableció en su Sentencia 2/1981, de 30 de enero, el principio de ne bis in idem, íntimamente unido a los principios de legalidad y de tipicidad recogidos en el artículo 25 de la Constitución, y que determina la imposibilidad de que recaiga duplicidad de sanciones en los casos en que se aprecie la identidad de sujeto, hecho y fundamento. Dicho principio se recoge actualmente con carácter general en el artículo 133 LRJ-PAC, que lo consagra abarcando todas sus manifestaciones, es decir ya sean dos sanciones administrativas o una administrativa y otra penal, y con carácter especifico lo ha venido haciendo la legislación urbanísti$\mathrm{Ca}^{70}$, de modo que actualmente el artículo 42 del Texto Refundido de la Ley del Suelo de 2008 establece que cuando con ocasión de los expedientes administrativos que se instruyan por infracción urbanística o contra la ordenación del territorio aparezcan indicios del carácter de delito o falta del propio hecho que motivó su incoación, el órgano competente para imponer la sanción lo pondrá en conocimiento del Ministerio Fiscal, a los efectos de exigencia de las responsabilidades de orden penal en que hayan podido incurrir los infractores, absteniéndose aquél de proseguir el procedimiento sancionador mientras la autoridad judicial no se haya pronunciado. La sanción penal excluirá la imposición de sanción administrativa, sin perjuicio de la adopción de medidas de reposición a la situación anterior a la comisión de la infracción.

criben en dos años, aunque también se prevé que sean tres años (Andalucía, Castilla-La Mancha, Extremadura y País Vasco), llegando a cuatro (Madrid, Murcia y Comunidad Valenciana); finalmente, las sanciones muy graves generalmente prescriben a los tres años, menos en los casos en que se prevé cuatro años (Madrid, Murcia, Navarra y Comunidad Valencia) o cinco años (Castilla-La Mancha, Extremadura y País Vasco).

70 Véase al respecto, E. Górriz Royo, Protección penal de la ordenación del territorio, op. cit. (cita 13), pp. 280 y ss. 
